\title{
Changes in the width of the tropical belt due to simple radiative forcing changes in the GeoMIP simulations
}

\author{
Nicholas A. Davis ${ }^{1}$, Dian J. Seidel ${ }^{2, *}$, Thomas Birner ${ }^{1}$, Sean M. Davis ${ }^{3}$, and Simone Tilmes ${ }^{4}$ \\ ${ }^{1}$ Department of Atmospheric Science, Colorado State University, Fort Collins, CO, USA \\ ${ }^{2}$ NOAA Air Resources Laboratory, College Park, MD, USA \\ ${ }^{3}$ NOAA Earth System Research Laboratory, Boulder, CO, USA \\ ${ }^{4}$ National Center for Atmospheric Research, Boulder, CO, USA \\ * retired \\ Correspondence to: Nicholas A. Davis (nadavis@atmos.colostate.edu)
}

Received: 20 April 2016 - Published in Atmos. Chem. Phys. Discuss.: 11 May 2016

Revised: 16 July 2016 - Accepted: 19 July 2016 - Published: 11 August 2016

\begin{abstract}
Model simulations of future climates predict a poleward expansion of subtropical arid climates at the edges of Earth's tropical belt, which would have significant environmental and societal impacts. This expansion may be related to the poleward shift of the Hadley cell edges, where subsidence stabilizes the atmosphere and suppresses precipitation. Understanding the primary drivers of tropical expansion is hampered by the myriad forcing agents in most model projections of future climate. While many previous studies have examined the response of idealized models to simplified climate forcings and the response of comprehensive climate models to more complex climate forcings, few have examined how comprehensive climate models respond to simplified climate forcings. To shed light on robust processes associated with tropical expansion, here we examine how the tropical belt width, as measured by the Hadley cell edges, responds to simplified forcings in the Geoengineering Model Intercomparison Project (GeoMIP). The tropical belt expands in response to a quadrupling of atmospheric carbon dioxide concentrations and contracts in response to a reduction in the solar constant, with a range of a factor of 3 in the response among nine models. Models with more surface warming and an overall stronger temperature response to quadrupled carbon dioxide exhibit greater tropical expansion, a robust result in spite of inter-model differences in the mean Hadley cell width, parameterizations, and numerical schemes. Under a scenario where the solar constant is reduced to offset an instantaneous quadrupling of carbon dioxide, the Hadley cells remain at their preindustrial width, de-
\end{abstract}

spite the residual stratospheric cooling associated with elevated carbon dioxide levels. Quadrupled carbon dioxide produces greater tropical belt expansion in the Southern Hemisphere than in the Northern Hemisphere. This expansion is strongest in austral summer and autumn. Ozone depletion has been argued to cause this pattern of changes in observations and model experiments, but the results here indicate that seasonally and hemispherically asymmetric tropical expansion can be a basic response of the general circulation to climate forcings.

\section{Introduction}

Earth's tropical belt can be defined by the band of rainy equatorial regions bordered by the arid subtropics to the north and the south. The Hadley cells, two thermally direct tropospheric circulations with rising motion near the Equator, significantly influence the surface climate of the tropical belt. Converging easterly near-surface trade winds transport moisture into the Intertropical Convergence Zone, a meandering front of convection that brings rain to the equatorial latitudes and heats tropical air through the condensation of water vapor. This heated air rises through the troposphere and diverges poleward into the upper troposphere of both hemispheres, eventually subsiding in the subtropics, where it dries and stabilizes the atmosphere against convection. Because of the strong latitudinal gradients in temperature and precipitation at the edges of the tropical belt, any shift in its edges 
could drive major changes in surface climate (Birner et al., 2014).

There is mounting evidence that such changes are already taking place. Soil moisture (Dorigo et al., 2012), precipitation (New et al., 2001; Zhang et al., 2007), and sea surface salinity (Helm et al., 2010) trends over the past several decades consistently indicate an intensification and poleward shift of the hydrological cycle. The intensification is widely considered to be driven primarily by increasing water vapor concentrations in a warming atmosphere (Held and Soden, 2006). A concurrent weakening of the Hadley circulation is predicted in models, reflecting the reduction in upward mass flux in a warmer climate (Mitas and Clement, 2006; Vecchi and Soden, 2007). The circulation changes that drive poleward shifts in the hydrological cycle are not as well understood. Further subtropical drying and a poleward expansion of arid lands are projected to continue (Lu et al., 2007; Scheff and Frierson, 2012; Feng and Fu, 2013).

Evidence of tropical expansion has been reported based on satellite observations of outgoing longwave radiation $(\mathrm{Hu}$ and $\mathrm{Fu}, 2007$; Johanson and $\mathrm{Fu}, 2009$; $\mathrm{Hu}$ et al., 2011; Fu and Lin, 2011) and total column ozone (Hudson et al., 2003; Hudson, 2012). Observational estimates of the tropical belt width based on dynamical fields, such as the subtropical ridges in sea level pressure, also indicate tropical expansion, although the trends are weaker than those based on outgoing longwave radiation and precipitation metrics (Hu et al., 2011).

Other metrics for the tropical belt edge latitudes, such as the latitudes of the jet streams (Archer and Caldeira, 2008; Fu and Lin, 2011; Davis and Birner, 2013) and the latitudes of the subtropical tropopause breaks (Seidel and Randel, 2007; Birner, 2010; Davis and Rosenlof, 2012; Lucas et al., 2012; Davis and Birner, 2013; Ao and Hajj, 2013; Lucas and Nguyen, 2015), indicate historical tropical expansion, as well. An expansion of the Hadley cells has been detected in reanalyses (Hu and Fu, 2007; Johanson and Fu, 2009; Stachnik and Schumacher, 2011; Davis and Rosenlof, 2012; Davis and Birner, 2013; Nguyen et al., 2013; Chen et al., 2014). Tropical expansion estimates based on reanalyses, however, may suffer from spurious trends and discontinuities in basic meteorological fields (Trenberth et al., 2001; Bengtsson et al., 2004). The rate of Hadley cell expansion and even the mean strength of the Hadley cells vary among the reanalyses (Stachnik and Schumacher, 2011), which could indicate that the meridional winds are not well constrained. There is also significant uncertainty in the observed rate of tropical expansion because it is highly variable for different metrics and data products (Birner, 2010; Davis and Rosenlof, 2012; Davis and Birner, 2013; Lucas et al., 2014).

Attributing surface impacts to tropical expansion and attributing tropical expansion itself to particular climate forcings is difficult given the number of external forcings changing over the historical period, as well as the impact of natural climate variability on the trends. Factors such as the Pacific
Decadal Oscillation, the El Niño-Southern Oscillation (Lu et al., 2008), and the Southern Annular Mode influence the tropical belt width and may explain non-negligible fractions of its historical trend (Grassi et al., 2012; Allen et al., 2014; Lucas and Nguyen, 2015; Garfinkel et al., 2015).

Climate model simulations offer an avenue for assessing the response of the Hadley cells and tropical belt to different climate forcings and forcing evolutions, and long integrations minimize the impact of interannual variability (Hawkins and Sutton, 2009). Both Lu et al. (2009) and Hu et al. (2013) found that significant tropical expansion occurs only when greenhouse gas concentrations increase in historical climate simulations. Increasing greenhouse gas concentrations in future climate simulations similarly cause the tropical belt to expand relative to its preindustrial control width (Gastineau et al., 2008), with the amount of expansion scaling with the concentration of greenhouse gases (Lu et al., 2007; Tao et al., 2015). However, Adam et al. (2014) have shown that the Hadley cell width is generally sensitive to changes in both mean sea surface temperatures and meridional temperature gradients. Any climate forcing that modifies mean temperatures or their gradients could thus drive variations in the tropical belt width. Stratospheric ozone depletion and its resulting polar stratospheric cooling have been argued to be a potentially dominant driver of Southern Hemisphere tropical expansion (Polvani et al., 2011b; Min and Son, 2013), and ozone recovery over the coming decades may oppose any future greenhouse-gas-driven expansion (Son et al., 2009; Polvani et al., 2011a). Black carbon, tropospheric ozone (Allen et al., 2012), and aerosols (Allen and Sherwood, 2011; Allen et al., 2014) may have also played a role in historical tropical expansion, especially in the Northern Hemisphere. While examining the response of climate models to realistic sets of past and future forcings is appealing, it is not ideal for identifying how the tropical belt responds to particular forcings. Many climate forcing agents are simultaneously changing in these simulations, and separating their effects is often intractable.

Idealized modeling, which involves changing a single climate forcing or model parameter, complements those more realistic simulations. The models are often simplified versions of fully coupled climate models that may solve only the equations of motion and thermodynamics without explicitly resolving radiation and convection. Polvani and Kushner (2002) and Kushner and Polvani (2004) found that stratospheric cooling in such an idealized model produced a poleward shift of the midlatitude jet. It also produced a poleward shift in the pattern of surface easterlies and westerlies which indicates an expansion of the tropical belt. While Lorenz and DeWeaver (2007) found that cooling the stratosphere and raising the height of the tropopause were sufficient to produce a poleward shift of the tropospheric jets, Tandon et al. (2011) found that stratospheric cooling without perturbing the tropopause height was sufficient to drive an expansion of the Hadley cells. Similar to Tandon et al. (2011), Maycock 
et al. (2013) found that idealized increases in stratospheric water vapor drove enhanced stratospheric cooling and a poleward shift of the tropospheric jets. Warming in the troposphere alone can also drive an expansion of the Hadley cells (Frierson et al., 2007; Tandon et al., 2013). Thus, stratospheric cooling and tropospheric warming can both drive poleward shifts in the circulation.

However, idealized models do not explicitly model clouds or cloud-related feedbacks. Convection is a fundamental aspect of the Hadley cells (Frierson, 2007), and cloud radiative effects can impact modeled circulation changes (Ceppi et al., 2012, 2014; Voigt and Shaw, 2015). Some studies have begun to bridge this gap by examining the response of comprehensive models to idealized and more realistic greenhouse gas forcings. While Grise and Polvani (2014) found evidence that Southern Hemisphere Hadley cell expansion scales with climate sensitivity, Vallis et al. (2015) found little relationship between the transient climate response and Hadley cell expansion. Studies have also found evidence of a seasonality (Polvani et al., 2011b) and a lack of seasonality (McLandress et al., 2011) in Southern Hemisphere expansion. The scaling and seasonality seem to emerge if there is a steady greenhouse gas forcing (e.g., as in Polvani et al., 2011b, and Grise and Polvani, 2014). Work is still needed to understand this response and how it may scale with other changes in the climate system.

In this study, we will examine the equilibrium response of the tropical belt to highly idealized forcings in the Geoengineering Model Intercomparison Project (GeoMIP) (Kravitz et al., 2011). GeoMIP, a companion project to the Coupled Model Intercomparison Project Phase 5 (CMIP5) (Taylor et al., 2012), is designed to improve the understanding of the response of the Earth system to idealizations of different proposed climate geoengineering activities. Geoengineering impacts aside, the GeoMIP experiments offer a unique opportunity to study the response of fully coupled climate models to very simple climate forcings, which may shed light on the processes responsible for observed past and possible future tropical width changes.

\section{Data and methods}

While numerous climate forcings can impact the width of the tropical belt, we focus on variations in carbon dioxide and insolation simulated in GeoMIP. Our analysis is based on monthly-mean output from nine climate models (Table 1) that performed three sets of experiments: the GeoMIP Geoengineering 1 (G1) experiment (Kravitz et al., 2011), the preindustrial control (piControl), and the abruptly quadrupled carbon dioxide $\left(4 \times \mathrm{CO}_{2}\right)$ experiments in CMIP5 (Taylor et al., 2012). The piControl experiment fixes all climate forcings at preindustrial levels to provide an estimate of the unperturbed climate system and will be the control experiment in this study. The $4 \times \mathrm{CO}_{2}$ experiment applies an in- stantaneous quadrupling of piControl carbon dioxide concentrations, while the G1 experiment balances this abrupt quadrupling with a decrease in the solar constant such that the global-mean top-of-atmosphere radiative forcing is zero (Kravitz et al., 2011). This crudely models the effect of a global climate intervention scheme based on albedo modification (National Research Council, 2015) but more generally tests the impact of a decrease in insolation on the climate system, with some relevance for paleoclimate research. We only use the G1 experiment from GeoMIP because of its simple forcing scheme that is applied uniformly in all models.

For the G1 experiment, not all models achieved a perfect cancellation of the top-of-atmosphere radiative forcings. Table 1 lists the top-of-atmosphere radiative forcing in the $4 \times \mathrm{CO}_{2}$ experiment and the residual top-of-atmosphere radiative forcing in the G1 experiment after the solar constant reduction for each model (e.g., Huneeus et al., 2014).

Because the $4 \times \mathrm{CO}_{2}$ and $\mathrm{G} 1$ experiments involve an abrupt forcing at the start of the simulation, we discard the first 5 years of each experiment, a conservative choice as the circulation metrics adjust to the abrupt forcing within 2 years. The piControl simulations from each model range from 500 to 3000 model years, the $4 \times \mathrm{CO}_{2}$ simulations range from 140 to 150 model years, and the G1 simulations range from 50 to 100 model years. For each experiment, we use the same number of model years from each model simulation based on the shortest simulation; e.g., for the piControl experiment we use the first 500 years from all of the model simulations.

All calculations and analyses use monthly-mean model output. For testing the significance of changes in the tropical belt edge latitudes and width we use two-sided Student's $t$ tests for the difference of means with unequal variances and sample sizes. The tests thus take into account the different lengths and internal variability of each experiment. We use the effective degrees of freedom, which are calculated using the lag-1 autocorrelation of the monthly-mean anomalies (Bretherton et al., 1999). This yields approximately $400^{\circ}$ of freedom for the G1 simulations and $4000^{\circ}$ of freedom for the piControl simulations, with some inter-model variability. Differences are deemed statistically significant for $p \leq 0.05$ (the $95 \%$ confidence level).

\subsection{Tropical belt edge metric}

We define the tropical belt edge latitudes as the latitudes where the vertically averaged mean meridional streamfunction is zero, poleward of its tropical maximum (minimum) in the Northern (Southern) Hemisphere (Davis and Birner, 2013). The tropical belt width is defined as the difference, in degrees latitude, between the Northern and Southern Hemisphere edge latitudes. The mean meridional streamfunction is the vertical integral of the zonal-mean meridional mass flux between a given level and the top of the atmosphere, and it is the primary field used to study variations in the Hadley cells' width and intensity. It is expressed mathematically as 
Table 1. The model name, modeling group or agency, the $4 \times \mathrm{CO}_{2}$ experiment top-of-atmosphere radiative forcing relative to piControl, and the G1 experiment residual top-of-atmosphere radiative forcing relative to the piControl experiment for each of the nine models examined. All radiative forcings are from Huneeus et al. (2014) and are in $\mathrm{W} \mathrm{m}^{-2}$. Information on the radiative forcings in the CSIRO-Mk3L-1-2 model is unavailable.

\begin{tabular}{llrr}
\hline Model & Group & $\begin{array}{r}4 \times \mathrm{CO}_{2} \text { radiative } \\
\text { forcing }\left(\mathrm{W} \mathrm{m}^{-2}\right)\end{array}$ & $\begin{array}{r}\mathrm{G} 1 \text { radiative } \\
\text { forcing }\left(\mathrm{W} \mathrm{m}^{-2}\right)\end{array}$ \\
\hline CanESM2 & Canadian Centre for Climate Modelling and Analysis & 8.0 & 0.0 \\
CCSM4 & National Center for Atmospheric Research & 6.2 & -0.5 \\
CSIRO-Mk3L-1-2 & Commonwealth Scientific and Industrial Research Organisation & $\mathrm{NA}$ & $\mathrm{NA}$ \\
GISS-E2-R & Goddard Institute for Space Studies & 7.8 & 1.4 \\
HadGEM2-ES & Met Office Hadley Centre for Climate Science and Services & 6.4 & 0.4 \\
IPSL-CM5A-MR & Institut Pierre Simon Laplace Climate Modelling Centre & 6.2 & 0.2 \\
MIROC-ESM & University of Tokyo, National Institute for Environmental Studies, & 8.7 & 0.0 \\
& and Japan Agency for Marine-Earth Science and Technology & & \\
MPI-ESM-LR & Max-Planck-Intitut für Meteorologie & 8.6 & 0.2 \\
NorESM1-M & Norwegian Climate Center & 6.8 & 0.4 \\
\hline
\end{tabular}

$\mathrm{NA}=$ not available

$\Psi(p, \phi)=\frac{2 \pi a \cos (\phi)}{g} \int_{p}^{0}[v] \mathrm{d} p$,

where $\Psi$ is the mean meridional streamfunction at the pressure $p$ and latitude $\phi,[v]$ is the zonal-mean meridional wind, $a=6.371 \times 10^{6} \mathrm{~m}$ is the mean radius of the Earth, and $g=9.81 \mathrm{~ms}^{-2}$ is the acceleration due to gravity. While the Hadley cell edge latitudes are often calculated as the latitudes where the $500 \mathrm{hPa}$ streamfunction is zero, the choice of a single, arbitrary pressure level subjects the metric to spurious trends due to mean-state changes, such as a deepening of the troposphere, and to inter-model differences in the circulation (Birner, 2010; Davis and Rosenlof, 2012; Davis and Birner, 2013). Instead we vertically average the streamfunction in pressure before calculating the edge latitudes. The interpretation of this vertical average of the streamfunction is simple: it measures the average meridional overturning circulation strength at a given latitude, and the latitude where it is zero indicates the separation of the Hadley and Ferrel cells.

We note that this metric and our analyses focus on the zonal mean. However, historical tropical expansion exhibits significant zonal asymmetries (Chen et al., 2014; Lucas and Nguyen, 2015), and some zonally asymmetric dynamics contribute to the longitudinal structure of the meridional overturning circulation (Karnauskas and Ummenhofer, 2014).

\subsection{Tropical belt edge locations}

Before analyzing the $4 \times \mathrm{CO}_{2}$ and $\mathrm{G} 1$ experiments, we will first examine the climatology of the tropical belt edge latitudes in the piControl experiment (Fig. 1). The median tropical belt edge latitudes in each hemisphere are comparable among the models. In general, models with more equa-

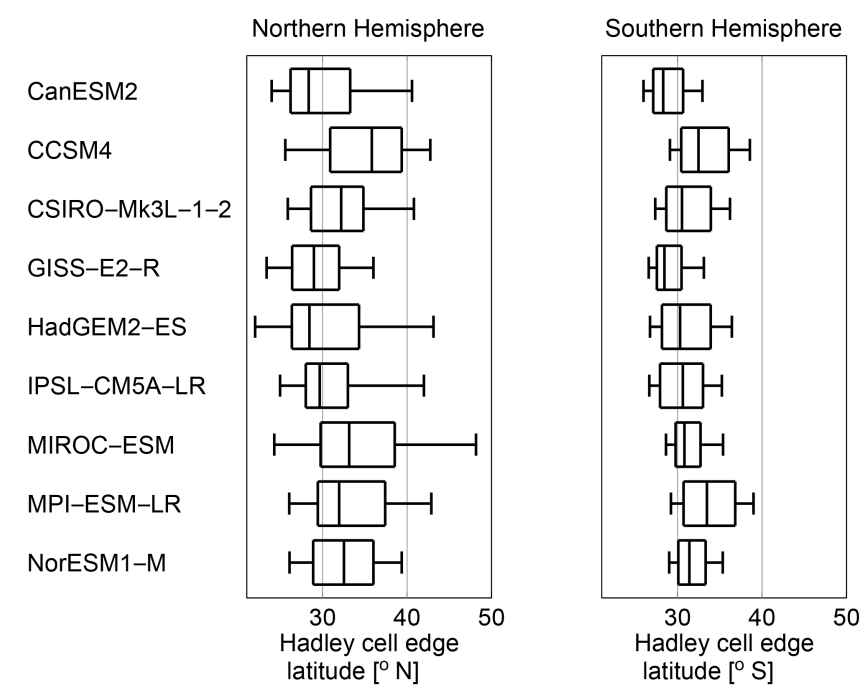

Figure 1. The piControl experiment climatology of the tropical belt edge latitudes for each of the nine models. The middle bar of each box represents the median, and the left and right bars of each box represent the lower and upper quartiles, respectively, of the tropical belt edge latitudes. Whiskers indicate the maximum and minimum tropical belt edge latitude for the piControl experiment.

torward edge latitudes in one hemisphere have more equatorward edge latitudes in the other hemisphere $\left(R^{2}=0.7\right)$. There is greater interannual variability in the Northern Hemisphere edge latitude, which is borne out in reanalyses and observations (Davis and Birner, 2013). Some models, including the IPSL-CM5A-LR and GISS-E2-R models, have little interannual variability in their Northern Hemisphere edge latitudes. 


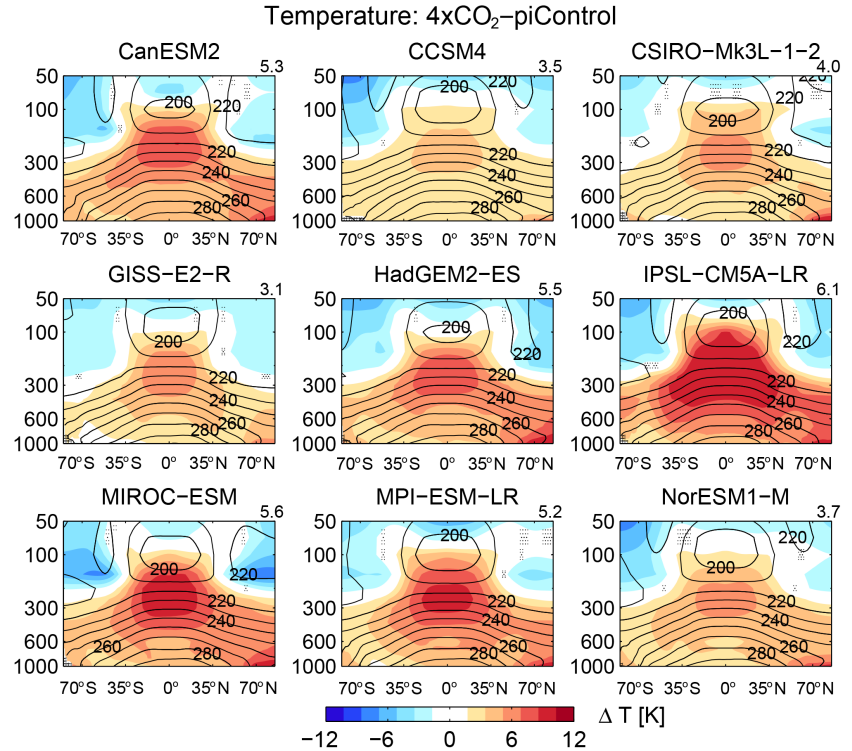

Figure 2. The difference in the zonal-mean temperature between the $4 \times \mathrm{CO}_{2}$ and piControl experiments for each of the nine models. The $4 \times \mathrm{CO}_{2}$ experiment temperature minus the piControl experiment temperature is shown in shading (Kelvin), while the piControl experiment temperature is shown by the black contours (Kelvin). Stippling indicates differences not significant at the $95 \%$ confidence level. The change in global-mean surface temperature (Kelvin) between the $4 \times \mathrm{CO}_{2}$ and piControl experiments is shown in the upper right of each panel.

\section{Temperature response}

We will first characterize the temperature changes in each model between the $4 \times \mathrm{CO}_{2}$ and piControl and between the G1 and piControl experiments. The motivation to examine the basic zonal-mean temperature response in all nine models is threefold: (1) temperature changes are associated with changes in the tropical belt width (e.g., Adam et al., 2014), (2) the zonal-mean temperature response may provide information about a model's sensitivity to different forcings, and (3) examining only the multi-model mean may obscure important information about the robustness of the response and its inter-model variations.

Quadrupled carbon dioxide concentrations drive the expected surface and tropospheric warming and stratospheric cooling (Manabe and Wetherald, 1967) (Fig. 2). The tropical upper-tropospheric warming is due to moist adiabatic adjustment communicating the surface warming to upper levels (Held et al., 1993; Romps, 2011). Enhanced Arctic warming, or "Arctic amplification", is partly due to decreases in surface albedo brought on by reductions in snow cover and sea ice (Pithan and Mauritsen, 2014) and enhanced downwelling longwave radiation through the so-called "ice-insulation" feedback (Burt et al., 2015). The stratospheric cooling is partly driven by enhanced infrared cooling to space due to in-

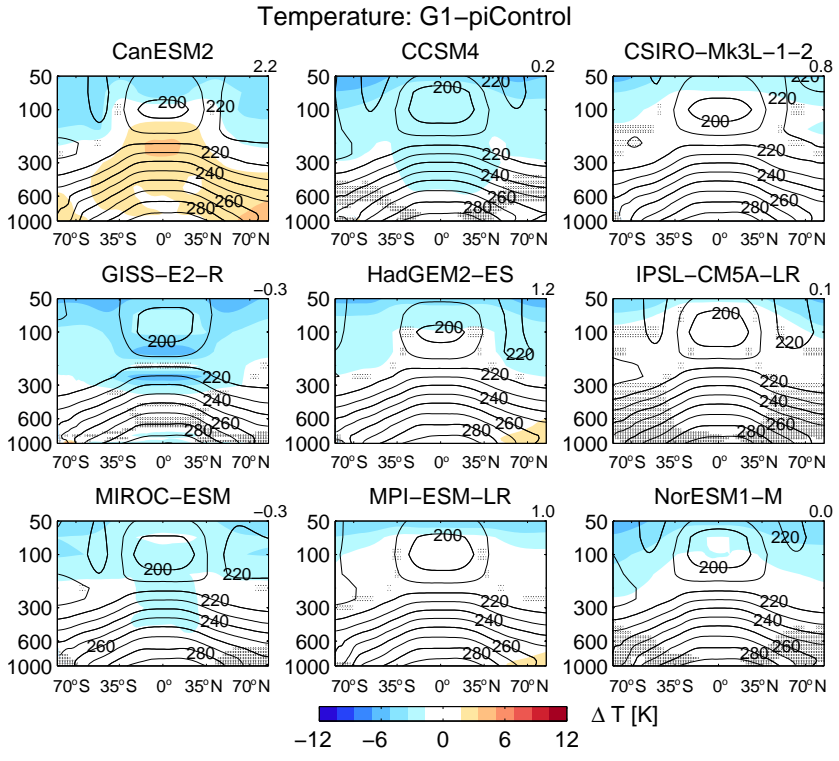

Figure 3. The difference in the zonal-mean temperature between the G1 and piControl experiments for each of the nine models. The G1 experiment temperature minus the piControl experiment temperature is shown in shading (Kelvin), while the piControl experiment temperature is shown by the black contours (Kelvin). Stippling indicates differences not significant at the $95 \%$ confidence level. The change in global-mean surface temperature (Kelvin) between the G1 and piControl experiments is shown in the upper right of each panel.

creased carbon dioxide concentrations. Other processes such as changes in the strength of the Brewer-Dobson circulation may contribute to the latitudinal structure of the cooling. While all models capture this canonical greenhouse gas response in zonal-mean temperature, the temperature changes vary by nearly a factor of 3 . The IPSL-CM5A-LR has the strongest response with $13 \mathrm{~K}$ upper-tropospheric and Arctic warming, while the CCSM4 model has the weakest response with $5 \mathrm{~K}$ upper-tropospheric and $8 \mathrm{~K}$ Arctic warming. The IPSL-CM5A-LR model also has the strongest surface temperature increase in the abrupt $4 \times \mathrm{CO}_{2}$ experiment at $6.1 \mathrm{~K}$, while the CCSM4 model has the second-weakest response at $3.5 \mathrm{~K}$.

The G1 experiment's solar constant reduction generally balances most of the warming from quadrupled carbon dioxide (Fig. 3). Because Fig. 3 shows the difference in temperature between the G1 and piControl experiments, it can be interpreted as the temperature response to $4 \times \mathrm{CO}_{2}$ that is not counteracted by the solar constant reduction in the G1 experiment. In the $\mathrm{G} 1$ experiment, the stratosphere is cooler than it is in the piControl experiment in all models. This is likely because of the reduction in absorbed solar radiation by ozone and infrared radiation emission by the (still enhanced) carbon dioxide concentrations. However, the troposphere is marginally cooler in some models (CCSM4, GISS-E2-R, and 


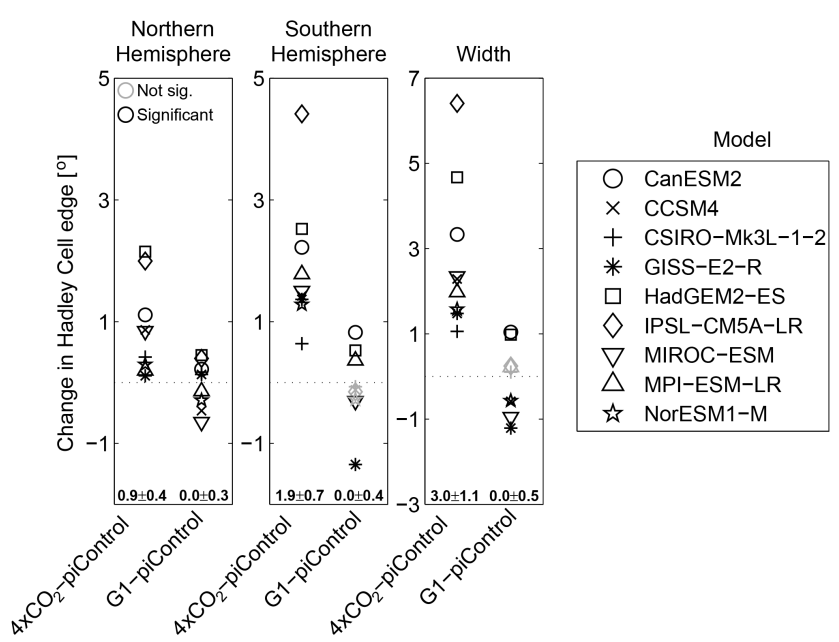

Figure 4. The change in the Hadley cell edge latitudes and width between the $4 \times \mathrm{CO}_{2}$ and piControl experiments and between the G1 and piControl experiments, for the Northern Hemisphere and Southern Hemisphere edge latitudes and for the total change in Hadley cell width. Positive values indicate poleward expansion or an increase in width. Models with edge latitude or width changes significant at the $95 \%$ confidence level are shown in black. The mean change in the tropical belt width or edge latitude and its $95 \%$ confidence interval in degrees latitude is shown at the bottom of each plot.

MIROC-ESM) and marginally warmer in others (CanESM2, HadGEM2-ES, and MPI-ESM-LR). Unlike the robust temperature response in the $4 \times \mathrm{CO}_{2}$ experiment, there is no robust residual warming or cooling in the troposphere in G1 compared to piControl. Contrary to expectations, the model with the strongest residual radiative forcing in the G1 experiment, GISS-E2-R, does not have a warmer troposphere, while one of the models with a radiative forcing of zero, CanESM2, has a significantly warmer troposphere. In the coming sections, we will explore how the tropical belt responds to these simple forcings and whether any processes could explain such changes.

\section{Tropical belt width response}

Quadrupled carbon dioxide drives a statistically significant expansion of the tropical belt as measured by the Hadley cell edge latitudes in both the Southern and Northern Hemisphere (Fig. 4). There is a large spread in the magnitude of tropical expansion, though, with values ranging from $1^{\circ}$ of total (width) expansion in the CSIRO-Mk3L-1-2 model to nearly $7^{\circ}$ of total expansion in the IPSL-CM5A-LR model (the model with the strongest temperature response to quadrupled carbon dioxide). The nearly factor-of-7 difference in the circulation response is far larger than the factor-of-2-3 temperature response difference.

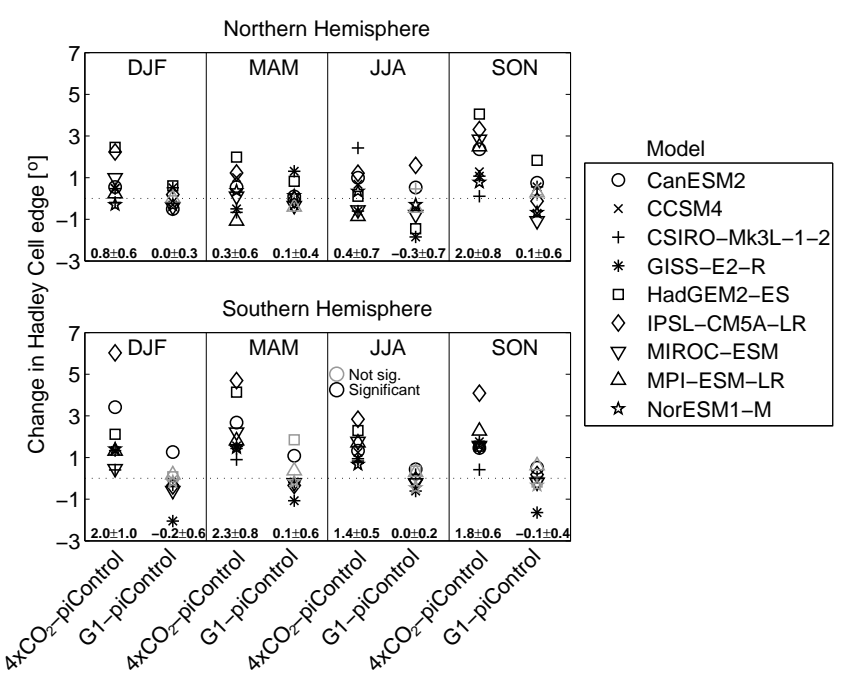

Figure 5. The seasonal change in the Hadley cell edge latitudes and width between the $4 \times \mathrm{CO}_{2}$ and piControl experiments and between the G1 and piControl experiments, for the Northern Hemisphere and Southern Hemisphere edge latitudes. Positive values indicate poleward expansion. Models with edge latitude changes significant at the $95 \%$ confidence level are shown in black. Values are shown for December through February (DJF), March through May (MAM), June through August (JJA), and September through November (SON). The mean change in the tropical belt width or edge latitude and its $95 \%$ confidence interval in degrees latitude is shown at the bottom of each plot.

More surprising is that the Southern Hemisphere expansion is on average twice the Northern Hemisphere expansion (Fig. 4). Southern Hemisphere stratospheric ozone depletion has been argued to be a dominant driver of the more rapid observed expansion of the Southern Hemisphere Hadley cell (Polvani et al., 2011b; Min and Son, 2013; Waugh et al., 2015). However, the results here indicate that, even with a hemispherically symmetric climate forcing which does not include ozone changes, the tropical belt responds asymmetrically with greater expansion in the Southern Hemisphere. Furthermore, the expansion is strongest in the Southern Hemisphere in austral summer and autumn (Fig. 5), consistent with Grise and Polvani (2016). These are the seasons when the stratospheric cooling due to ozone depletion is expected to have its greatest impact on Southern Hemisphere expansion trends as ozone is depleted throughout austral spring.

The solar constant reduction in the G1 experiment counteracts most of the $\mathrm{CO}_{2}$-driven expansion in the $4 \times \mathrm{CO}_{2}$ experiment, despite the residual stratospheric cooling. This suggests that stratospheric cooling on the order of $1-6 \mathrm{~K}$ with the maximum cooling over the poles (Fig. 3) is not sufficient to appreciably widen the tropical belt. However, the altitude of the cooling may be an important factor in determining whether the tropical belt responds or not. For example, in idealized dry simulations Tandon et al. (2011) found that 
extratropical stratospheric cooling must extend down to the tropopause to drive a strong circulation response. In the G1 experiment, the cooling is well above the typical height of the extratropical tropopause (Fig. 3), which is generally located at approximately $250-300 \mathrm{hPa}$. This may be why there is no robust tropical expansion in the G1 experiment. Processes in fully coupled models that are not represented in idealized dry simulations, including cloud and radiation feedbacks, could act to further damp the response of the tropical belt to stratospheric cooling.

For most models the differences between their G1 and piControl experiment edge latitudes and width are small, often less than $\pm 0.5^{\circ}$ latitude (with an average difference of zero). Just as there is no robust tropospheric temperature difference between the G1 and piControl experiments, there is no robust residual tropical expansion or contraction. Changes in the tropical belt width are not statistically significantly correlated with the residual radiative forcings in the G1 experiment.

In the Northern Hemisphere (Fig. 5), tropical expansion in response to increased carbon dioxide concentrations is approximately constant from December-January-February (DJF) through June-July-August (JJA). It is twice as large in September-October-November (SON). The enhanced expansion in boreal autumn is consistent with realistic (Hu et al., 2013; Kang and Lu, 2012) and more idealized (Kang and Lu, 2012) CMIP5 forcing simulations and with historical reanalyses ( $\mathrm{Hu}$ and $\mathrm{Fu}, 2007)$. While Allen et al. (2012) proposed that the observed tropical expansion in Northern Hemisphere summer and autumn was driven by the combined effects of black carbon and tropospheric ozone, it appears that increased carbon dioxide concentrations alone could also drive some of this enhanced expansion. As a caveat, however, the seasonality of Northern Hemisphere tropical expansion is not particularly robust as the tropical belt contracts in some models and seasons in response to quadrupled carbon dioxide concentrations. This may arise from the opposing effects of the direct radiative forcing and changes in sea surface temperatures on land-sea temperature contrasts (Shaw and Voigt, 2015). The resulting circulation response appears to be senstitive to which of the two dominates.

To explore whether the large range in the responses and the asymmetric response in the two hemispheres are associated with any particular zonal-mean temperature structures, we composite the difference in temperature between the $4 \times \mathrm{CO}_{2}$ and piControl experiments in the four models with the greatest and in the four models with the least total tropical expansion (Fig. 6). Both groups show the same general pattern of tropospheric warming and stratospheric cooling. In fact, the difference in the temperature response to quadrupled carbon dioxide between the models with the greatest and the least tropical expansion itself resembles the temperature response to quadrupled carbon dioxide. An exception can be found in the upper stratosphere, where the
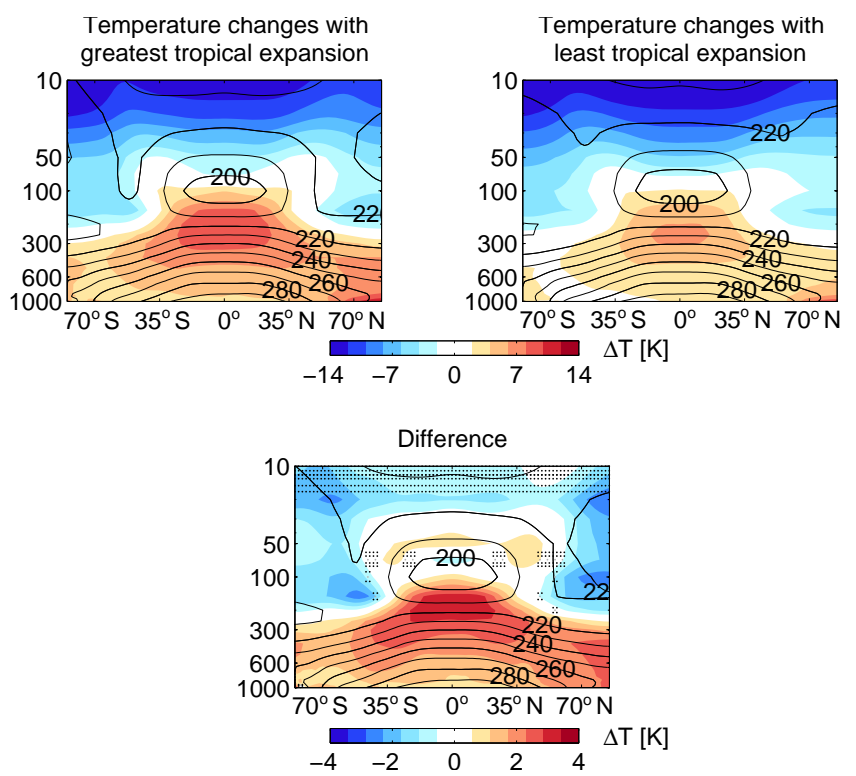

Figure 6. The difference in zonal-mean temperature between the $4 \times \mathrm{CO}_{2}$ and piControl experiments in the four models with the greatest tropical expansion (upper left) and in the four models with the least tropical expansion (upper right). The $4 \times \mathrm{CO}_{2}$ experiment minus the piControl experiment temperatures are shown in shading (Kelvin), while the piControl experiment temperatures are shown by the black contours (Kelvin). The difference in the $4 \times \mathrm{CO}_{2}$ experiment minus the piControl experiment temperatures between the models with the greatest and least tropical expansion is shown on the bottom, with shading indicating the difference (Kelvin) and black contours indicating the mean piControl experiment temperature (Kelvin) for all models. Stippling indicates changes not significant at the $95 \%$ confidence level.

cooling is similar between the two subsets of models. There is not a substantial difference between the separate composites on Northern and Southern Hemisphere expansion, but both show a slightly weaker stratospheric cooling signal (not shown). Overall there are no unique relationships in the strength of the tropical upper-tropospheric amplification, the Arctic amplification, the surface warming, or the stratospheric cooling. Rather, these temperature responses all consistently scale among the models with greater tropical expansion.

\subsection{Inter-model differences in the tropical width response and associated thermodynamic changes}

Subtropical static stability increases due to tropical uppertropospheric amplification may be important for driving tropical expansion (Fig. 6). Held (2000) derived a scaling theory for the Hadley cell width based on the critical shear for baroclinic instability in the Phillips two-layer model (Phillips, 1951). If one assumes that the poleward flow in the Hadley cells conserves angular momentum, and that the flow terminates at the latitude of the onset of baroclinic instability, then 


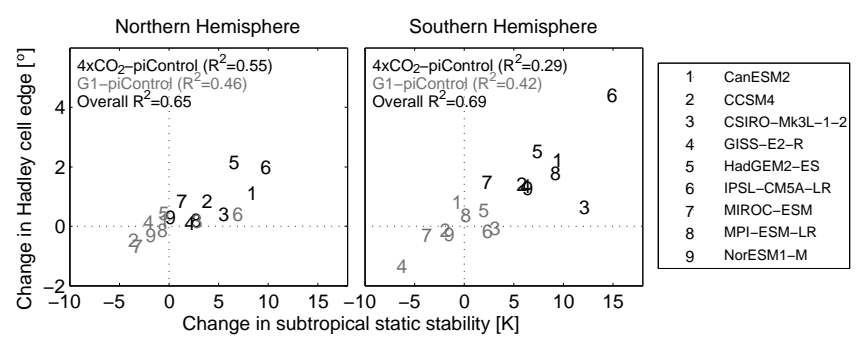

Figure 7. The change in the Hadley cell edge latitude versus the change in subtropical static stability in the Northern Hemisphere and in the Southern Hemisphere. For both hemispheres, positive changes in the Hadley cell edge latitude indicate poleward expansion. Shown are values for the $4 \times \mathrm{CO}_{2}$ experiment minus the piControl experiment (black) and for the G1 experiment minus the piControl experiment (gray). The percent of the inter-model variation in the change in the Hadley cell edge latitude explained by the change in subtropical static stability between each experiment is indicated in each plot.

the edge latitude of the Hadley cell is only a function of the tropopause height and the gross static stability (the difference between the potential temperature of the tropopause and the surface). Increases in static stability or tropopause height would both act to further stabilize the flow against baroclinic instability and allow the Hadley cell to expand poleward. Lu et al. (2008) found changes in static stability to be strongly correlated with changes in the Hadley cell edge latitude, and a cursory scale analysis shows that the scaling theory is dominated by the static stability term for typical variations in static stability and tropopause height (Frierson et al., 2007). For these reasons we will focus exclusively on changes in subtropical static stability.

The Held (2000) scaling theory has been used to study tropical expansion in models ranging from dry dynamical cores to fully coupled climate models (Frierson et al., 2007; Lu et al., 2007, 2008), although modified scaling theories that relax the angular momentum conservation constraint (Kang and $\mathrm{Lu}, 2012$ ), as well as theories based on other criteria (Lu et al., 2008; Korty and Schneider, 2008; Tandon et al., 2013; Levine and Schneider, 2015), may be more realistic. Similar to Levine and Schneider (2015), we evaluate the gross static stability, hereafter "subtropical static stability", at the tropical belt edge latitude. We define the subtropical static stability as the difference in potential temperature between $100 \mathrm{hPa}$ (approximately the tropical tropopause) and $1000 \mathrm{hPa}$ (approximately the surface) averaged over $5^{\circ}$ of latitude equatorward of the tropical belt edge latitude for each month in each hemisphere.

In both hemispheres, tropical expansion between the $4 \times \mathrm{CO}_{2}$ and piControl experiments is associated with an increase in subtropical static stability, with the increase in stability explaining $29-55 \%$ of the inter-model variation in tropical expansion (Fig. 7). This relationship also holds for the tropical expansion and contraction between the G1 and

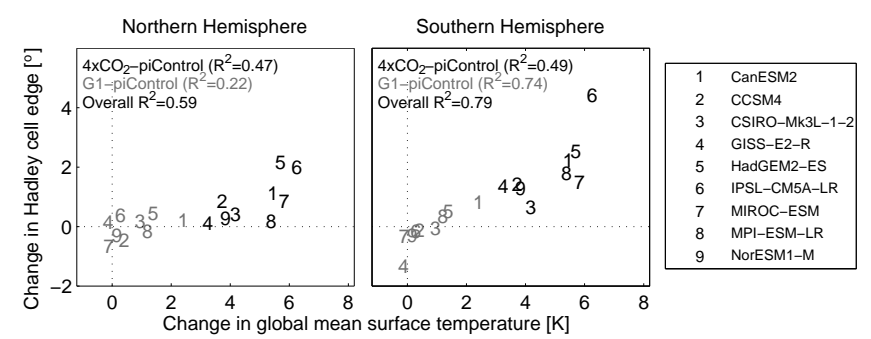

Figure 8. As in Fig. 7 but for the change in the Hadley cell edge latitude versus the change in global-mean surface temperature in the Northern Hemisphere and in the Southern Hemisphere.

piControl experiments, where changes in static stability explain $42-46 \%$ of the total inter-model variation in the tropical belt edge latitudes. These results are noteworthy for two reasons. Firstly, the relationships remain linear for small and large changes in subtropical static stability and the Hadley cell edge latitude. Secondly, despite differences in the models' mean edge latitudes and their parameterizations of convection and other processes, and despite a dearth of physical inter-model relationships (Davis and Birner, 2016), this particular relationship is robust across models and scenarios.

Tropical upper-tropospheric temperatures tend to warm more than surface temperatures due to moist adiabatic adjustment (Held et al., 1993; Romps, 2011). Because the moist adiabatic lapse rate scales with surface temperature, any change in static stability in the tropics and subtropics reflects changes in surface temperature. Accordingly, tropical expansion in both hemispheres also scales with increases in globalmean surface temperature (Fig. 8), explaining $47-49 \%$ of the inter-model variation in tropical expansion between the $4 \times \mathrm{CO}_{2}$ and piControl experiments. Despite being the residual rather than the forced response, increases in global-mean surface temperature also explain $74 \%$ of the inter-model variation in tropical expansion in the Southern Hemisphere in the G1 experiment, though less so in the Northern Hemisphere. Compared to the Southern Hemisphere, Northern Hemisphere tropical expansion seems to scale nonlinearly for large increases in global-mean surface temperature.

The seasonality of these correlations (not shown) generally reflects the seasonality of the response (Fig. 5). For example, tropical expansion in the Northern and Southern Hemispheres is most highly correlated with the change in global-mean surface temperature in $\operatorname{SON}\left(R^{2}=0.31\right)$ and $\operatorname{MAM}\left(R^{2}=0.43\right)$, respectively. In the other seasons, no significant correlation is found between the change in globalmean surface temperature and tropical expansion in the Northern Hemisphere.

Tropical expansion as measured by the total change in tropical belt width disproportionately increases as the globalmean surface temperature increases (Fig. 9). This reflects the nonlinearity seen in the expansion of the Northern Hemisphere tropical belt edge latitudes. The change in the tropical 


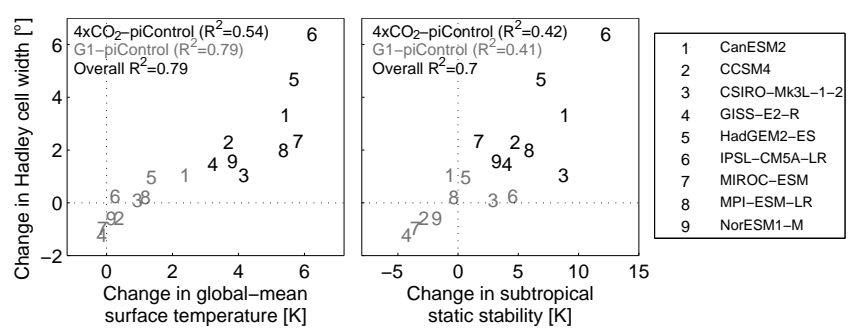

Figure 9. The change in the total Hadley cell width versus the change in global-mean surface temperature and the change in subtropical static stability. Positive changes in the Hadley cell width indicate tropical expansion. Shown are values for the $4 \times \mathrm{CO}_{2}$ experiment minus the piControl experiment (black) and for the $\mathrm{G} 1$ experiment minus the piControl experiment (gray). The percent of the inter-model variation in the change in the Hadley cell edge latitude explained by the change in global-mean surface temperature and the change in subtropical static stability between each experiment is indicated in each plot.

belt width is better correlated with the change in global-mean surface temperature than with the change in subtropical static stability, explaining $54-79 \%$ of the total inter-model variation in the change in the tropical belt width.

We also examined Arctic warming and tropical uppertropospheric warming separately, as the two may have different impacts on tropical expansion and/or may explain some additional inter-model variation in the tropical belt response. However, both of these indices are correlated with the total change in global-mean surface temperature (Fig. 10), even seasonally (not shown). Tropical upper-tropospheric temperature changes are well-correlated with the change in globalmean surface temperature across the models for both the difference between the $4 \times \mathrm{CO}_{2}$ and piControl experiments and the difference between the $\mathrm{G} 1$ and piControl experiments. For the Arctic warming, the correlations do not depend upon whether one defines Arctic amplification as the total temperature change at the surface in the Arctic (as is done here) or as the difference between the total temperature change at the surface in the Arctic minus the change in global-mean surface temperature; if one is correlated with global-mean surface temperature, the other will be as well.

\section{Conclusions}

We have examined the equilibrium response of the tropical belt to simple radiative forcings in the GeoMIP experiments. Quadrupled concentrations of carbon dioxide in the $4 \times \mathrm{CO}_{2}$ experiment produce the canonical temperature response and drive significant tropical expansion in all models. The insolation reduction in the G1 experiment generally counteracts the carbon-dioxide-induced tropospheric warming but leaves the stratosphere colder than it was in the piControl experiment. The lack of any significant change in the tropical belt width between the G1 and piControl experiments indicates

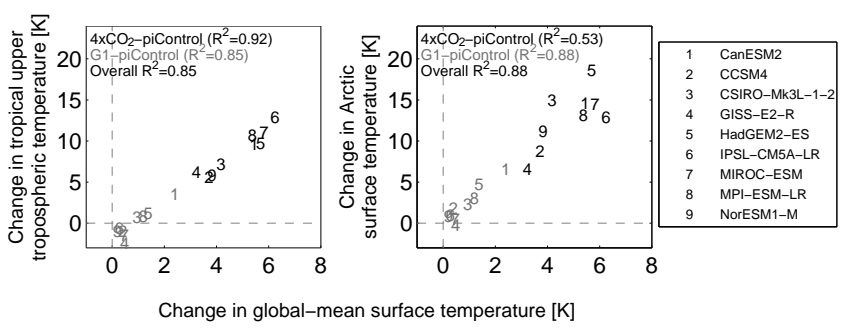

Figure 10. The change in tropical upper-tropospheric temperature versus the change in global-mean surface temperature (left), and the change in Arctic surface temperature versus the change in globalmean surface temperature (right), between the $4 \times \mathrm{CO}_{2}$ and piControl experiments (black) and between the $\mathrm{G} 1$ and piControl experiments (gray). Tropical upper-tropospheric temperature is defined as the mean temperature between 200 and $300 \mathrm{hPa}$ and between $10^{\circ} \mathrm{S}$ and $10^{\circ} \mathrm{N}$. Arctic temperature is defined as the mean surface temperature between 75 and $90^{\circ} \mathrm{N}$.

that broad stratospheric cooling alone may not drive tropical expansion, at least when the cooling does not extend down to the tropopause.

The expansion in response to quadrupled carbon dioxide concentrations is greater in the Southern Hemisphere and peaks in austral summer and autumn, consistent with recent findings by Grise and Polvani (2016), who also analyzed the $4 \times \mathrm{CO}_{2}$ experiment. Both responses have previously been identified as signatures of Antarctic ozone depletion on observed Southern Hemisphere tropical expansion. They also appear to reflect the basic response of the circulation to simple hemispherically symmetric, non-ozone climate forcings. This does not imply that ozone depletion and other climate forcings have not contributed to observed tropical expansion. Rather, it may be that ozone depletion and increased greenhouse gas concentrations have together enhanced the expansion in the Southern Hemisphere and in summer and autumn. The Southern Hemisphere Hadley cell may exist in a different dynamical regime than the Northern Hemisphere cell (Davis and Birner, 2013) due to the Southern Hemisphere cell's strong coupling to the eddy-driven jet (Kang and Polvani, 2011; Ceppi and Hartmann, 2013; Staten and Reichler, 2014). This jet has a more robust poleward shift in response to greenhouse gas increases than its Northern Hemisphere counterparts (Barnes and Polvani, 2013), which may enhance Southern Hemisphere tropical expansion. Further, the Hadley cells are more susceptible to the influence of extratropical Rossby waves in summer (Schneider and Bordoni, 2008), which may contribute to the seasonality of the expansion in both hemispheres.

Models with a stronger temperature response to increased carbon dioxide (which includes stronger surface, uppertropospheric, and Arctic warming and stronger stratospheric cooling) have greater tropical expansion. While tropical expansion scales with increases in both subtropical static stability and global-mean surface temperature, these indices effec- 
tively measure the same thermodynamic response because of moist adiabatic adjustment. Increases in global-mean surface temperature can explain up to $79 \%$ of the total inter-model variation in tropical expansion, noteworthy because it occurs within the inter-model space of fully coupled climate models. Different mean states (Kidston and Gerber, 2010), the representation of parameterized processes (Frierson, 2007), the strength of cloud feedbacks (Feldl and Bordoni, 2016), and model design choices such as horizontal resolution (Landu et al., 2014; Lorant and Royer, 2001; Davis and Birner, 2016) can all influence the circulation and its response. Tropical belt width changes are thus part and parcel of global climate change. They are strongly correlated with changes in other key climate features and are not a separate phenomenon. Tropical expansion could be considered as robust a response of the climate system to increasing greenhouse gas concentrations as an acceleration of the hydrological cycle.

How the temperature or static stability changes could actually drive tropical expansion is an open question. While the dynamical response is relatively fast, occurring within the first several years of the abrupt $4 \times \mathrm{CO}_{2}$ experiment, the increase in global-mean surface temperature takes much longer. Rather than being indicative of a mechanism for expansion, it is more accurate to conclude that dynamical sensitivity as measured by the Hadley cells scales with climate sensitivity, at least in response to changes in carbon dioxide concentrations and insolation.

While it is consistent with the modeled tropical expansion, the scaling theory used here includes some unrealistic assumptions. Angular momentum is not perfectly conserved in the poleward flow of the Hadley cell due to eddy momentum fluxes (Schneider, 2006), and the boundary between the Hadley and Ferrel cells is shaped by these eddy fluxes (Schneider, 2006; Lu et al., 2008; Ceppi and Hartmann, 2013; Choi et al., 2014). While the scaling theory can be adjusted to take into account the degree to which eddy fluxes draw the circulation away from angular momentum conservation (Kang and Lu, 2012), some bootstrap or input of the properties of the eddies is still needed to form a complete theoretical scaling for the Hadley cell width (Held, 2000). Further, localized (Tandon et al., 2011) and even nonlocalized cooling in the subtropical lower stratosphere (Butler et al., 2010) can drive variations in the Hadley cell width, potentially independent of changes to tropospheric static stability. This must be accounted for by any theory for the width of the Hadley cells and their response to radiative forcings.

Additionally, baroclinic instability is generally a feature of the eddy-driven jets, which can be well separated from the subtropical jets at the edges of the Hadley cells. Despite the inter-model correlation between tropical expansion and increases in static stability, increases in static stability may not be the only process associated with tropical expansion. Instead, changes to the eddy phase speeds that lead to poleward shifts in the latitudes of wave breaking (Chen and Held, 2007) may be responsible for poleward shifts of the Hadley cell edges (Ceppi and Hartmann, 2013). Both occur simultaneously with increasing greenhouse gas concentrations and global-mean surface temperatures. It is therefore impossible to exclude other factors and conclude that the static stability increases alone drive tropical expansion.

Both Arctic warming and tropical upper-tropospheric warming scale with increases in global-mean surface temperature. Separating these influences on the tropical belt and any other feature of the climate system is not feasible in the experiments examined here and may not be possible in projections of future climate. Despite the significant variation in the magnitude of the model response to simple forcings, we find a robust physical scaling throughout the climate system, between the tropics and the poles and between the thermodynamics and the circulation.

\section{Data availability}

Access to CMIP5 model output requires registration with the Earth System Grid Federation. Further information can be found at http://cmip-pcmdi.llnl.gov/cmip5/. CMIP5 is registered with the Registry of Research Data Repositories, doi:10.17616/R3X64R.

Acknowledgements. Two anonymous reviewers are thanked for their constructive comments. We thank all participants of the Geoengineering Model Intercomparison Project and their model development teams, the CLIVAR/WCRP Working Group on Coupled Modeling for endorsing GeoMIP, and the scientists managing the Earth System Grid Federation data nodes who have assisted with making GeoMIP output available. We also thank Ben Kravitz for supplying some model output. We acknowledge the World Climate Research Programme's Working Group on Coupled Modeling, which is responsible for CMIP, and we thank the climate modeling groups for producing and making available their model output. Nicholas Davis was supported by a National Science Foundation Graduate Research Fellowship. The National Center for Atmospheric Research is supported by the National Science Foundation.

Edited by: H. Wang

Reviewed by: two anonymous referees

\section{References}

Adam, O., Schneider, T., and Harnik, N.: Role of Changes in Mean Temperatures versus Temperature Gradients in the Recent Widening of the Hadley Circulation, J. Climate, 27, 7450-7461, doi:10.1175/JCLI-D-14-00140.1, 2014.

Allen, R. J. and Sherwood, S. C.: The impact of natural versus anthropogenic aerosols on atmospheric circulation in the Community Atmosphere Model, Clim. Dynam., 36, 1959-1978, doi:10.1007/s00382-010-0898-8, 2011.

Allen, R. J., Sherwood, S. C., Norris, J. R., and Zender, C. S.: Recent Northern Hemisphere tropical expansion primarily driven 
by black carbon and tropospheric ozone, Nature, 485, 350-354, doi:10.1038/nature11097, 2012.

Allen, R. J., Norris, J. R., and Kovilakam, M.: Influence of anthropogenic aerosols and the Pacific Decadal Oscillation on tropical belt width, Nat. Geosci., 7, 270-274, doi:10.1038/ngeo2091, 2014.

Ao, C. O. and Hajj, A. J.: Monitoring the width of the tropical belt with GPS radio occultation measurements, Geophys. Res. Lett., 40, 6236-6241, doi:10.1002/2013GL058203, 2013.

Archer, C. L. and Caldeira, K.: Historical trends in the jet streams, Geophys. Res. Lett., L08803, doi:10.1029/2008GL033614, 2008.

Barnes, E. A. and Polvani, L.: Response of the Midlatitude Jets, and of Their Variability, to Increased Greenhouse Gases in the CMIP5 Models, J. Climate, 26, 7117-7135, doi:10.1175/JCLID-12-00536.1, 2013.

Bengtsson, L., Hodges, K. I., and Hagemann, S.: Sensitivity of the ERA40 reanalysis to the observing system: determination of the global atmospheric circulation from reduced observations, Tellus A, 56, 456-471, doi:10.1111/j.1600-0870.2004.00079.x, 2004.

Birner, T.: Recent widening of the tropical belt from global tropopause statistics: Sensitivities, J. Geophys. Res., 115, D23109, doi:10.1029/2010JD014664, 2010.

Birner, T., Davis, S. M., and Seidel, D. J.: The changing width of Earth's tropical belt, Phys. Today, 67, 38-44, doi:10.1063/PT.3.2620, 2014.

Bretherton, C. S., Widmann, M., Dymnikov, V. P., Wallace, J. M., and Blade, I.: The Effective Number of Spatial Degrees of Freedom of a Time-Varying Field, J. Climate, 12, 1990-2009, doi:10.1175/1520-0442(1999)012<1990:TENOSD>2.0.CO;2, 1999.

Burt, M. A., Randall, D. A., and Branson, M. D.: Dark Warming, J. Climate, 29, 705-718, doi:10.1175/JCLI-D-15-0147.1, 2015.

Butler, A. H., Thompson, D. W. J., and Heikes, R.: The Steady-State Atmospheric Circulation Response to Climate Change-like Thermal Forcings in a Simple General Circulation Model, J. Climate, 23, 3474-3496, doi:10.1175/2010JCLI3228.1, 2010.

Ceppi, P. and Hartmann, D. L.: On the Speed of the Eddy-Driven Jet and the Width of the Hadley Cell in the Southern Hemisphere, J. Climate, 26, 3450-3465, doi:10.1175/JCLI-D-12-00414.1, 2013.

Ceppi, P., Hwang, Y.-T., Frierson, D. M. W., and Hartmann, D. L.: Southern Hemisphere jet latitude biases in CMIP5 models linked to shortwave cloud forcing, Geophys. Res. Lett., 39, L19708, doi:10.1029/2012GL053115, 2012.

Ceppi, P., Zelinka, M. D., and Hartmann, D. L.: The response of the Southern Hemispheric eddy-driven jet to future changes in shortwave radiation in CMIP5, Geophys. Res. Lett., 41, 32443250, doi:10.1002/2014GL060043, 2014.

Chen, G. and Held, I. M.: Phase speed spectra and the recent poleward shift of Southern Hemisphere surface westerlies, Geophys. Res. Lett., 34, L21805, doi:10.1029/2007GL031200, 2007.

Chen, S., Wei, K., Chen, W., and Song, L.: Regional changes in the annual mean Hadley circulation in recent decades, J. Geophys. Res., 119, 7815-7832, doi:10.1002/2014JD021540, 2014.

Choi, J., Son, S.-W., Lu, J., and Min, S.-K.: Further observational evidence of Hadley cell widening in the Southern Hemisphere, J. Climate, 27, 5538-5559, doi:10.1002/2014GL059426, 2014.
Davis, N. A. and Birner, T.: Seasonal to multi-decadal variability of the width of the tropical belt, J. Geophys. Res., 118, 7773-7787, doi:10.1002/jgrd.50610, 2013.

Davis, N. A. and Birner, T.: Climate model biases in the width of the tropical belt, J. Climate, 29, 1935-1954, doi:10.1175/JCLID-15-0336.1, 2016.

Davis, S. M. and Rosenlof, K. H.: A Multidiagnostic Intercomparison of Tropical-Width Time Series Using Reanalyses and Satellite Observations, J. Climate, 25, 1061-1078, doi:10.1175/JCLID-11-00127.1, 2012.

Dorigo, W., de Jeu, R., Chung, D., Parinussa, R., Liu, Y., Wagner, W., and Fernàndez-Prieto, D.: Evaluating global trends (19882010) in harmonized multi-satellite surface soil moisture, Geophys. Res. Lett., 39, L18405, doi:10.1029/2012GL052988, 2012.

Feldl, N. and Bordoni, S.: Characterizing the Hadley Circulation Response through Regional Climate Feedbacks, J. Climate, 29, 613-622, doi:10.1175/JCLI-D-15-0424.1, 2016.

Feng, S. and Fu, Q.: Expansion of global drylands under a warming climate, Atmos. Chem. Phys., 13, 10081-10094, doi:10.5194/acp-13-10081-2013, 2013.

Frierson, D. M. W.: The Dynamics of Idealized Convection Schemes and Their Effect on the Zonally Averaged Tropical Circulation, J. Atmos. Sci., 64, 1959-1976, doi:10.1175/JAS3935.1, 2007.

Frierson, D. M. W., Lu, J., and Chen, G.: Width of the Hadley cell in simple and comprehensive general circulation models, Geophys. Res. Lett., 34, L18804, doi:10.1029/2007GL031115, 2007.

Fu, Q. and Lin, P.: Poleward Shift of Subtropical Jets Inferred from Satellite-Observed Lower Stratospheric Temperatures, J. Climate, 24, 5597-5603, doi:10.1175/JCLI-D-11-00027.1, 2011.

Garfinkel, C. I., Waugh, D. W., and Polvani, L. M.: Recent Hadley cell expansion: The role of internal atmospheric variability in reconciling modeled and observed trends, Geophys. Res. Lett., 42, 10824-10831, doi:10.1002/2015GL066942, 2015.

Gastineau, G., Treut, H. L., and Li, L.: Hadley circulation changes under global warming conditions indicated by coupled climate models, Tellus, 60A, 863-884, doi:10.1111/j.16000870.2008.00344.x, 2008.

Grassi, B., Redaelli, G., Canziani, P. O., and Visconti, G.: Effect of the PDO Phase on the Tropical Belt Width, J. Climate, 25, 3282-3290, doi:10.1175/JCLI-D-11-00244.1, 2012.

Grise, K. M. and Polvani, L. M.: Is climate sensitivity related to dynamical sensitivity? A Southern Hemisphere perspective, Geophys. Res. Lett., 41, 534-540, doi:10.1002/2013GL058466, 2014.

Grise, K. M. and Polvani, L. M.: Is climate sensitivity related to dynamical sensitivity?, J. Geophys. Res., 121, 5159-5176, doi:10.1002/2015JD024687, 2016.

Hawkins, E. and Sutton, R.: The potential to Narrow Uncertainty in Regional Climate Predictions, B. Am. Meteorol. Soc., 90, 10951107, doi:10.1175/2009BAMS2607.1, 2009.

Held, I. M.: The general circulation of the atmosphere, in: 2000 Program in Geophysical Fluid Dynamics, Woods Hole Oceanographic Institude, Woods Hole, Mass., 30-36, 2000.

Held, I. M. and Soden, B. J.: Robust Responses of the Hydrological Cycle to Global Warming, J. Climate, 19, 5685-5699, doi:10.1175/JCLI3990.1, 2006.

Held, I. M., Hemler, R. S., and Ramaswamy, V.: RadiativeConvective Equilibrium with Explicit Two-Dimensional Moist 
Convection, J. Atmos. Sci., 50, 3909-3927, doi:10.1175/15200469(1993)050<3909:RCEWET>2.0.CO;2, 1993.

Helm, K. P., Bindoff, N. L., and Church, J. A.: Changes in the global hydrological-cycle inferred from ocean salinity, Geophys. Res. Lett., 37, L18701, doi:10.1029/2010GL044222, 2010.

$\mathrm{Hu}$, Y. and Fu, Q.: Observed poleward expansion of the Hadley circulation since 1979, Atmos. Chem. Phys., 7, 5229-5236, doi:10.5194/acp-7-5229-2007, 2007.

$\mathrm{Hu}$, Y., Zhou, C., and Liu, J.: Observational evidence for the poleward expansion of the Hadley circulation, Adv. Atmos. Sci., 28, 33-44, doi:10.1007/s00376-010-0032-1, 2011.

$\mathrm{Hu}$, Y., Tao, L., and Liu, J.: Poleward Expansion of the Hadley Circulation in CMIP5 Simulations, Adv. Atmos. Sci., 30, 790-795, doi:10.1007/s00376-012-2187-4, 2013.

Hudson, R. D.: Measurements of the movement of the jet streams at mid-latitudes, in the Northern and Southern Hemispheres, 1979 to 2010, Atmos. Chem. Phys., 12, 7797-7808, doi:10.5194/acp12-7797-2012, 2012.

Hudson, R. D., Frolov, A. D., Andrade, M. F., and Follette, M. B.: The total ozone field separated into meteorological regimes, J. Atmos. Sci., 60, 1669-1677, doi:10.1175/15200469(2003)060<1669:TTOFSI>2.0.CO;2, 2003.

Huneeus, N., Boucher, O., Alterskjær, K., Cole, J. N. S., Curry, C. L., Ji, D., Jones, A., Kravitz, B., Kristjánsson, J. E., Moore, J. C., Muri, H., Niemeier, U., Rasch, P., Robock, A., Singh, B., Schmidt, H., Schulz, M., Tilmes, S., Watanabe, S., and Yoon, J.-H.: Forcings and feedbacks in the GeoMIP ensemble for a reduction in solar irradiance and increase in $\mathrm{CO}_{2}$, J. Geophys. Res., 119, 5226-5239, doi:10.1002/2013JD021110, 2014.

Johanson, C. M. and Fu, Q.: Hadley Cell Widening: Model Simulations versus Observations, J. Climate, 22, 2713-2725, doi:10.1175/2008JCLI2620.1, 2009.

Kang, S. M. and Lu, J.: Expansion of the Hadley Cell under Global Warming: Winter versus Summer, J. Climate, 25, 8387-8393, doi:10.1175/JCLI-D-12-00323.1, 2012.

Kang, S. M. and Polvani, L. M.: The interannual relationship between the eddy-driven jet and the edge of the Hadley cell, J. Climate, 24, 563-568, doi:10.1175/2010JCLI4077.1, 2011.

Karnauskas, K. B. and Ummenhofer, C. C.: On the dynamics of the Hadley circulation and subtropical drying, Clim. Dynam., 42, 2259-2269, doi:10.1007/s00382-014-2129-1, 2014.

Kidston, J. and Gerber, E. P.: Intermodel variability of the poleward shift of the austral jet stream in the CMIP3 integrations linked to biases in 20th century climatology, Geophys. Res. Lett., 37, L09708, doi:10.1029/2010GL042873, 2010.

Korty, R. L. and Schneider, T.: Extent of Hadley circulations in dry atmospheres, Geophys. Res. Lett., 35, L23803, doi:10.1029/2008GL035847, 2008.

Kravitz, B., Robock, A., Boucher, O., Schmidt, H., Taylor, K. E., Stenchikov, G., and Schulz, M.: The Geoengineering Model Intercomparison Project (GeoMIP), Atmos. Sci. Lett., 12, 162167, doi:10.1002/asl.316, 2011.

Kushner, P. J. and Polvani, L. M.: Stratosphere-troposphere coupling in a relatively simple AGCM: The role of eddies, J. Climate, 17, 629-639, doi:10.1175/JCLI4007.1, 2004.

Landu, K., Leung, L. R., Hagos, S., Vinoj, V., Rauscher, S. A., Ringler, T., and Taylor, M.: The Dependence of ITCZ Structure on Model Resolution and Dynamical Core in Aquaplanet
Simulations, J. Climate, 27, 2375-2385, doi:10.1175/JCLI-D13-00269.1, 2014

Levine, X. J. and Schneider, T.: Baroclinic Eddies and the Extent of the Hadley Circulation: An Idealized GCM Study, J. Atmos. Sci., 72, 2744-2761, doi:10.1175/JAS-D-14-0152.1, 2015.

Lorant, V. and Royer, J.-F.: Sensitivity of Equatorial Convection to Horizontal Resolution in Aquaplanet Simulations with a Variable-Resolution GCM, Mon. Weather Rev., 129, 2730-2745, doi:10.1175/1520-0493(2001)129<2730:SOECTH>2.0.CO;2, 2001.

Lorenz, D. J. and DeWeaver, E. T.: Tropopause height and zonal wind response to global warming in the IPCC scenario intergrations, J. Geophys. Res., 112, D10119, doi:10.1029/2006JD008087, 2007.

Lu, J., Vecchi, G. A., and Reichler, T.: Expansion of the Hadley cell under global warming, Geophys. Res. Lett., 118, L06805, doi:10.1029/2006GL028443, 2007.

Lu, J., Chen, G., and Frierson, D. M. W.: Response of the Zonal Mean Atmospheric Circulation to El Niño versus Global Warming, J. Climate, 21, 5835-5851, doi:10.1175/2008JCLI2200.1, 2008.

Lu, J., Deser, C., and Reichler, T.: Cause of the widening of the tropical belt since 1958, Geophys. Res. Lett., L03802, doi:10.1029/2008GL036076, 2009.

Lucas, C. and Nguyen, H.: Regional characteristics of tropical expansion and the role of climate variability, J. Geophys. Res., 120, 6809-6824, doi:10.1002/2015JD023130, 2015.

Lucas, C., Nguyen, H., and Timbal, B.: An observational analysis of Southern Hemisphere tropical expansion, J. Geophys. Res., 117, D17112, doi:10.1029/2011JD017033, 2012.

Lucas, C., Timbal, B., and Nguyen, H.: The expanding tropics: a critical assessment of the observational and modeling studies, WIREs Clim. Change, 5, 89-112, doi:10.1002/wcc.251, 2014.

Manabe, S. and Wetherald, R. T.: Thermal Equilibrium of the Atmosphere with a Given Distribution of Relative Humidity, J. Atmos. Sci., 24, 241-259, doi:10.1175/15200469(1967)024<0241:TEOTAW>2.0.CO;2, 1967.

Maycock, A. C., Joshi, M. M., Shine, K. P., and Scaife, A. A.: The Circulation Response to Idealized Changes in Stratospheric Water Vapor, J. Climate, 26, 545-561, doi:10.1175/JCLI-D-1200155.1, 2013.

McLandress, C., Shepherd, T. G., Scinocca, J. F., Plummer, D. A., Sigmond, M., Jonsson, A. I., and Reader, M. C.: Separating the Dynamical Effects of Climate Change and Ozone Depletion. Part II: Southern Hemisphere Troposphere, J. Climate, 24, 18501868, doi:10.1175/2010JCLI3586.1, 2011.

Min, S.-K. and Son, S.-W.: Multimodel attribution of the Southern Hemisphere Hadley cell widening: Major role of ozone depletion, J. Geophys. Res., 118, 3007-3015, doi:10.1002/jgrd.50232, 2013.

Mitas, C. M. and Clement, A.: Recent behavior of the Hadley cell and tropical thermodynamics in climate models and reanalyses, Geophys. Res. Lett., 33, L01810, doi:10.1029/2005GL024406, 2006.

National Research Council: Climate Intervention: Reflecting Sunlight to Cool Earth, Washington, D. C., doi:10.17226/18988, 2015 . 
New, M., Todd, M., Hulme, M., and Jones, P.: Precipitation measurements and trends in the twentieth century, Int. J. Climatol., 21, 1899-1922, doi:10.1002/joc.680, 2001.

Nguyen, H., Evans, A., Lucas, C., Smith, I., and Timbal, B.: The Hadley circulation in reanalyses: climatology, variability and expansion, J. Climate, 26, 3357-3376, doi:10.1175/JCLI-D-1200224.1, 2013.

Phillips, N. A.: A simple three-dimensional model for the study of larger-scale extratropical flow patterns, J. Meteorol., 8, 381-394, doi:10.1175/1520-0469(1951)008<0381:ASTDMF>2.0.CO;2, 1951.

Pithan, F. and Mauritsen, T.: Arctic amplification dominated by temperature feedbacks in contemporary climate models, Nat. Geosci., 7, 181-184, doi:10.1038/ngeo2071, 2014.

Polvani, L. M. and Kushner, P. J.: Tropospheric response to stratospheric perturbations in a relatively simple general circulation model, Geophys. Res. Lett., 29, L014284, doi:10.1029/2001GL014284, 2002.

Polvani, L. M., Previdi, M., and Deser, C.: Large cancellation, due to ozone recory, of future Southern Hemisphere atmospheric circulations trends, Geophys. Res. Lett., 38, L04707, doi:10.1029/2011GL046712, 2011a.

Polvani, L. M., Waugh, D. W., Correa, G. J. P., and Son, S.-W.: Stratospheric ozone depletion: the main driver of 20th Century atmospheric circulation changes in the Southern Hemisphere, J. Climate, 24, 795-812, doi:10.1175/2010JCLI3772.1, $2011 \mathrm{~b}$.

Romps, D. M.: Response of Tropical Precipitation to Global Warming, J. Atmos. Sci., 68, 123-138, doi:10.1175/2010JAS3542.1, 2011.

Scheff, J. and Frierson, D. M. W.: Robust future precipitation declines in CMIP5 largely reflect the poleward expansion of model subtropical dry zones, Geophys. Res. Lett., 39, L18704, doi:10.1029/2012GL052910, 2012.

Schneider, T.: The general circulation of the atmosphere, Annu. Rev. Earth Pl. Sc., 34, 655-688, doi:10.1146/annurev.earth.34.031405.125144, 2006.

Schneider, T. and Bordoni, S.: Eddy-Mediated Regime Transitions in the Seasonal Cycle of a Hadley Circulation and Implications for Monsoon Dynamics, J. Atmos. Sci., 65, 915-933, doi:10.1175/2007JAS2415.1, 2008.

Seidel, D. J. and Randel, W. J.: Recent widening of the tropical belt: Evidence from tropopause observations, J. Geophys. Res., 112, D20113, doi:10.1029/2007JD008861, 2007.

Shaw, T. A. and Voigt, A.: Tug of war on summertime circulation between radiative forcing and sea surface warming, Nat. Geosci., 8, 560-566, doi:10.1038/ngeo2449, 2015.
Son, S.-W., Tandon, N. F., Polvani, L. M., and Waugh, D. W.: Ozone hole and Southern Hemisphere climate change, Geophys. Res. Lett., 36, L15605, doi:10.1029/2009GL038671, 2009.

Stachnik, J. P. and Schumacher, C.: A comparison of the Hadley circulation in modern reanalyses, J. Geophys. Res., 116, D22102, doi:10.1029/2011JD016677, 2011.

Staten, P. W. and Reichler, T.: On the ratio between shifts in the eddy-driven jet and the Hadley cell edge, Clim. Dynam., 42, 1229-1242, doi:10.1007/s00382-013-1905-7, 2014.

Tandon, N. F., Polvani, L. M., and Davis, S. M.: The response of the tropospheric circulation to water vapor-like forcings in the stratosphere, J. Climate, 24, 5713-5720, doi:10.1175/JCLI-D11-00069.1, 2011

Tandon, N. F., Gerber, E. P., Sobel, A. H., and Polvani, L. M.: Understanding Hadley Cell expansion versus contraction: insights from simplified models and implications for recent observations, J. Climate, 26, 4304-4321, doi:10.1175/JCLI-D-1200598.1, 2013

Tao, L., Hu, Y., and Liu, J.: Anthropogenic forcing on the Hadley circulation in CMIP5 simulations, Clim. Dynam., 46, 33373350, doi:10.1007/s00382-015-2772-1, 2015.

Taylor, K. E., Stouffer, R. J., and Meehl, G. A.: An overview of CMIP5 and the experiment design, B. Am. Meteorol. Soc., 93, 485-498, doi:10.1175/BAMS-D-11-00094.1, 2012.

Trenberth, K. E., Stepaniak, D. P., Hurrell, J. W., and Fiorino, M.: Quality of Reanalyses in the Tropics, J. Climate, 14, 1499-1510, doi:10.1175/1520-0442(2001)014<1499:QORITT>2.0.CO;2, 2001.

Vallis, G. K., Zurita-Gotor, P., Cairns, C., and Kidston, J.: Response of the large-scale structure of the atmosphere to global warming, Q. J. Roy. Meteor. Soc., 141, 1479-1501, doi:10.1002/qj.2456, 2015.

Vecchi, G. A. and Soden, B. J.: Global warmng and the weakening of the tropical circulation, J. Climate, 20, 4316-4340, doi:10.1175/JCLI4258.1, 2007.

Voigt, A. and Shaw, T. A.: Circulation response to warming shaped by radiative changes of clouds and water vapour, Nat. Geosci., 8 , 102-106, doi:10.1038/ngeo2345, 2015.

Waugh, D. W., Garfinkel, C. I., and Polvani, L. M.: Drivers of the Recent Tropical Expansion in the Southern Hemisphere: Changing SSTs or Ozone Depletion?, J. Climate, 28, 6581-6586, doi:10.1175/JCLI-D-15-0138.1, 2015.

Zhang, X., Zwiers, F. W., Hegerl, G. C., Lambert, F. H., Gillett, N. P., Solomon, S., Stott, P. A., and Nozawa, T.: Detection of human influence on twentieth-century precipitation trends, Nature, 448, 461-465, doi:10.1038/nature06025, 2007. 